\title{
ATLAS OF THE ORAL AND MAXILLOFACIAL SURGERY CLINICS OF NORTH AMERICA
}

\section{FORTHCOMING ISSUES}

\section{March 2017}

Management of Mandibular Condylar Fractures Martin B. Steed, Editor

\section{September 2017}

Oral Manifestations of Systemic Diseases Joel J. Napeñas, Editor

\section{PREVIOUS ISSUES}

March 2016

Techniques in Orthognathic Surgery

Steven M. Sullivan, Editor

\section{September 2015}

Adjuncts for Care of the Surgical Patient Sidney L. Bourgeois Jr, Editor

March 2015

Diagnosis and Management of Neck Masses David E. Webb, Editor

\section{RELATED INTEREST}

Oral and Maxillofacial Surgery Clinics of North America, May 2016, Volume 28, Issue 2 Management of the Cleft Patient Kevin S. Smith, Editor

Available at: www.oralmaxsurgery.theclinics.com

THE CLINICS ARE NOW AVAILABLE ONLINE! 